\title{
Integration of Environmental Economics to Build Economic Behaviors
}

\author{
Amin Pujiati ${ }^{1}$, Khasan Setiaji ${ }^{1 . *}$, Hana Netti Purasani ${ }^{1}$, and Nina Farliana ${ }^{1}$ \\ ${ }^{1}$ Faculty of Economics, Universitas Negeri Semarang, Semarang - Indonesia
}

\begin{abstract}
Environmental degradation is a global concern and an increasing one. Education is critical for promoting sustainable development and improving the capacity of people to address environment and development issues. As a conservation university, Universitas Negeri Semarang (UNNES) has an interest to integrate conservation values into every academician's learning. One of the ways is by integrating environmental economics into its learning. This research aims at testing whether there is an influence of integration of environmental economics on the environmental economic behaviors of students of Economic Faculty, Universitas Negeri Semarang. In achieving the objective above, this research uses an experimental approach with factorial design. The research results show that (1) integration of environmental economics is conducted by learning planning, implementation and evaluation, (2) student's understanding of environmental economy is low, (3) direct integration of environmental economics through Problem Base Learning is able to improve the experiment class's environmental economic behavior, (4) integration of environmental economics does not reduce student's ability in mastering the main competencies in economy, (5) environmental economic behavior is formed from various elements that affect it.
\end{abstract}

Keywords: Integration; Environmental Economics; Economic Behaviors.

\section{Introduction}

Environmental issue phenomena need special attention since currently many natural resources declines in their quality as the result of environmental pollution, such as increasing amount of pollution from vehicles, pollution from wastes of factories and industries in residential environment, increasing environmental degradation because of economic behaviors, production and consumption patterns which only consider temporary and unsustainable interests or disregard continuing biological existences [1]. These problems will cause more and more strain on the earth's natural resources and habitats [2].

Indonesia is an archipelagic nation with a water area more dominant over its land. Potential natural disaster in Indonesia is relatively high in intensity and variance. On the other hand, adolescents as the future generation have a great contribution in saving earth for it to avoid various disasters caused by human activities which often threaten the preservation of the earth [3]. This needs the community's behavior and moral that consider the sustainable environment, which includes economic behavior [4].

The quality of Indonesia environment from 2015 up to 2018 is reflected in the index of environmental indifference behavior (IPKLH) which is 65.14. It means good enough. Further, it consists of a water management dimension, private transportation, energy, and waste management. The index of energy management dimension is the lowest, 0.16 . This illustrates that the energy management in Indonesia is categorized as good. While waste management has the highest index, 0.72 . This shows that the environmental indifference behavior of Indonesian to waste management is high [5].

What they can do is to realize various opportunities to reduce the impacts of global warming by, one of which, consuming environmentally friendly products [6]. This is based on their awareness that their consumption process will directly affect the environment [7]. Adolescent's awareness of consumption is formed because of their behavioral pattern of responsibility to the environment and respecting other existences on earth [8]. Behavior can be changed through the education process, starting with an understanding of the importance of human existence, which states that human is part of the ecosystem. Every economic activity conducted will certainly result in effect, as Hanley, N., Shogren, J.F., \& White [9] proposes that various problems will arise in environmental and social dimensions. Basically, human action cannot be separated from their activities to fulfill their needs as part of the economic system, which contains environmental and social dimensions.

Pro-environmental behavior has been defined by Peattie [10] as "the purchasing and non-purchasing decisions made by consumers, based at least partly on environmental or social criteria". Concerning the relationship between consumption behavior and ecology, Prugh Thomas, Herman Daly, Robert Goodland, John H

\footnotetext{
Corresponding author: setiaji@mail.unnes.ac.id
} 
Cumberland [11] states that in fulfilling the needs, human should pay attention to ecology by utilizing nature responsibly and avoid the free view of values directing to a rational trait. As publicly known, natural resources constitute non-renewable natural wealth, thus they need wise management and use for the sustainability of next generation life.

Basically, the ecological economy gives a message of the environmental values which must accompany any economic actions, either in production, consumption or distribution of economic goods and services. Wahjoedi [12] proposes that economic behavior is directed to respect and maintain the balance of nature and environment, back to nature, no harm to nature. These environmental values have become an internationally required trend, thus nationally it should be put into real economic action. Its implication in economic education is that environmental insight must be included in theoretical and implementing studies through the economic learning process in educational institutions, both in and out of school [13].

Universitas Negeri Semarang had implemented educational sustainable development (ESD) that benefited the campus, and influence the society [14]. A sustainable university campus can be defined as higher education institution that addresses, involves and promotes the minimization of environmental, economics, societal and health negative effects in the use of their resources in its main functions of teaching, research, outreach and partnership, and stewardship to help society make the transition to sustainable lifestyles [15]. Universitas Negeri Semarang got the fifth rank in Indonesia and went to $85^{\text {th }}$ rank in the world for sustainable university in 2018 based on UI Green Metric (UIGM) World University Rankings. Universitas Negeri Semarang assessed the environmental performance of all faculties and unit through (H-Bat) program integrated to UIGM. In this assessment faculty of economics got the third rank unit and faculty in 2018. Previous research conducted by Setiaji [16] concludes that the internalization of environmental economic behavior is made through the integration of environmental economics in Economic Faculty, Universitas Negeri Semarang. Therefore, it is necessary to test the model of integration of environmental economics in Economic Faculty, Universitas Negeri Semarang. To achieve this purpose, this research proposes the following research questions:

- RQ1. How is the integrated model of environmental economics designed in teaching and learning?

- RQ2. How are the students' understandings of environmental economics?

- RQ3. To test the effectiveness of integrated model of environmental education in improving the environmental economics?

\section{Literature Review}

Environmental education as one of the catalysts for sustainable development [17]. Leal Filho [18] addressed the importance of the introduction of sustainability components into university activities. The role of universities in promoting sustainability is very important because they can generate new knowledge on sustainable development and train the leaders of tomorrow [19]. The factors that may influence someone's views on sustainability are knowledge, background, experience, perception, values, and context [20]. The professional preparation and performance of teachers is the cornerstone for the appropriate functioning of schools; it is the factor that most affects the quality of school education [21]. It is therefore not surprising that any strategy aimed at integrating Environmental Education (EE) into the school system considers teacher training as one of its main strategic elements and it was defined as the 'priority of priorities' in the United Nations Programme [22].

Most of previous studies focus on the analysis of Sustainable Development (SD) which is integrated at the curriculum; and they do not discuss about the environment only [23]. In fact, two tendencies can be distinguished in the literature regarding SD integration in curricula: horizontal or vertical integration. In horizontal integration, SD is interwoven within different courses of the curriculum, while vertical integration can be understood as the organization of separate SD courses within the curriculum [24].

\section{Methods and Sources}

This is an experimental research with a factorial design $[24,25]$. The integration of environmental economics into the subject of Economy of Indonesia, with the topic of investment climate reformation, constitutes the variable treatment given to the experiment students (experiment group). The research population is undergraduate students of the Economic Education Department, Economic Faculty, Universitas Negeri Semarang. The samples are taken from undergraduate students of Economic Education class $\mathrm{A}$ and $\mathrm{B}$ who are taking the subject Economy of Indonesia. The data are analyzed using Independent Samples Test.

\section{Analysis and Discussion}

\subsection{Integration of Environmental Economics}

Learning activity starts with planning, implementation, and evaluation of learning. Therefore, we can observe the process of integration of environmental economics in learning planning, learning implementation and how the assessment of learning outcome. Environmental economics is integrated into the learning process in Economic Faculty, Universitas Negeri Semarang in the following manner.

- Direct Integration.

This is made by inserting environmental economic materials into subjects. Economic subjects which are related to environmental economics such as the subjects Economy of Indonesia, Agricultural Economics, Political Economics, Macroeconomics, 
and other subjects are inserted into the syllabus, Course Unit, Course Contract, and Competence Standard, Basic Competence.

- Indirect Integration.

Economic subjects which are related to sustainable economics such as the subjects Monetary Economics, Econometrics, Economic Mathematics, and other subjects are integrated indirectly by inserting environmental economic elements into the learning process through moral appeal and example.

The empirical models of integration of environmental economics adapted from the stages of integration of character building into subject matters [27] are:

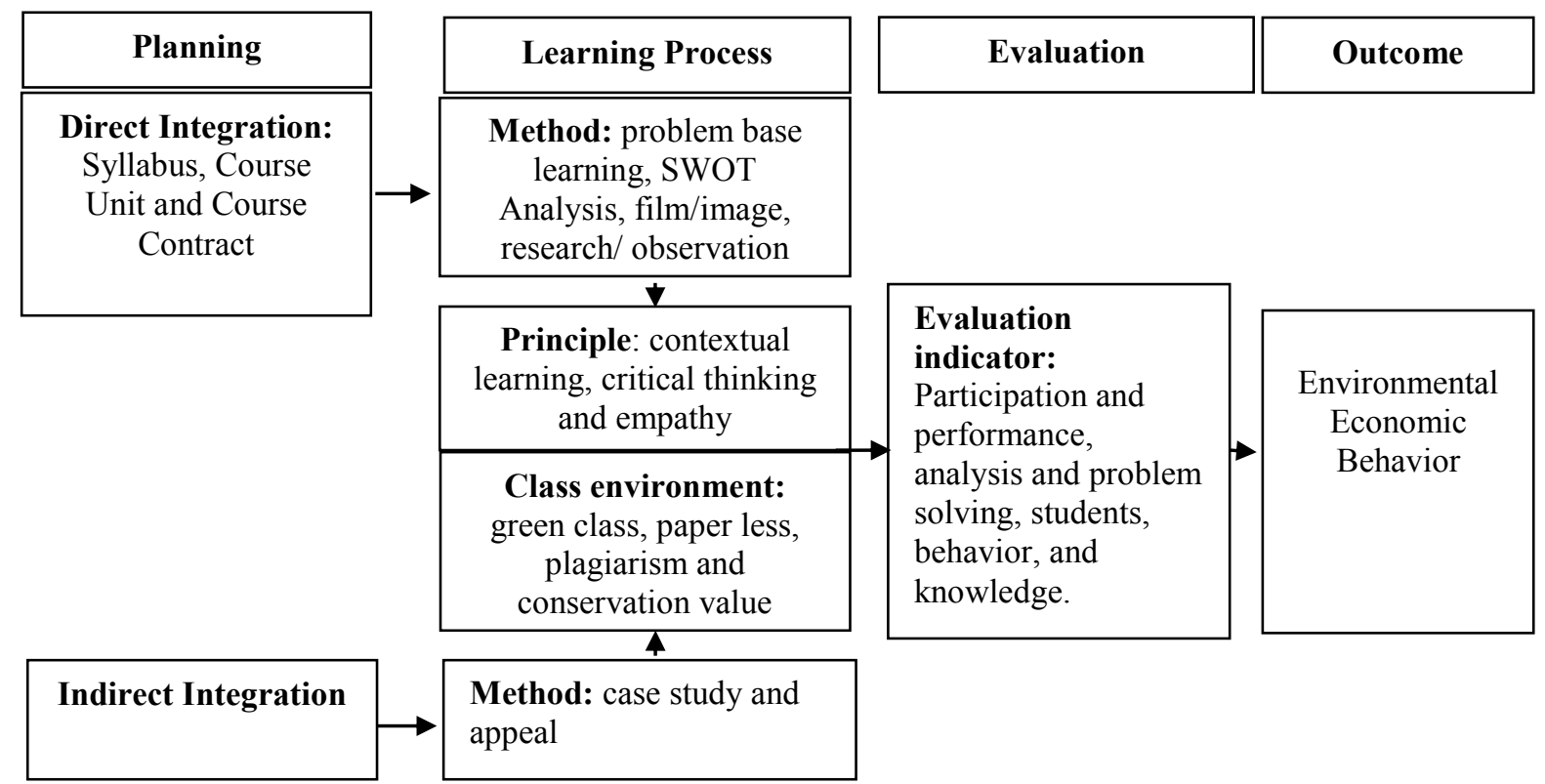

Fig. 1. Model Integration of Environmental Economics

\subsection{Integration of Environmental Economics with Problem Base Learning}

The integration of environmental economics is conducted on the subject Economy of Indonesia, with the topic of investment climate reformation. Integration of environmental economic education is conducted to the Economic Education class (experiment class) through problem based on learning model. Meanwhile, presentation and discussion learning models are used for the Economic Education class B (control class).

\subsubsection{Planning}

Integration of environmental economics on the subject Economy of Indonesia, with the topic of investment climate reformation is inserted into learning planning directly. The integration is conducted directly into the Syllabus, Course Unit and Course Contract of Economy of Indonesia as presented in the following figure.

\begin{tabular}{|c|c|c|c|c|c|}
\hline 1. Investment & 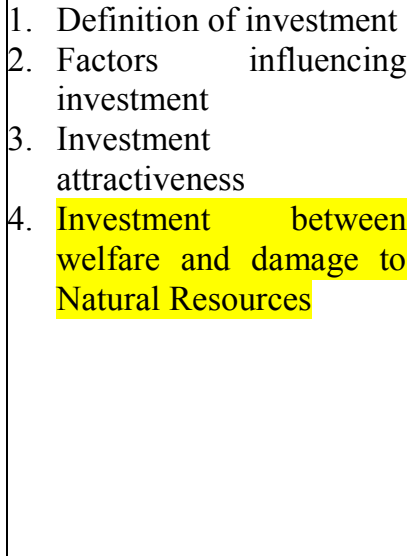 & $\begin{array}{l}\text { 1. Describe definition } \\
\text { of investment. } \\
\text { 2. Mention factors } \\
\text { influencing } \\
\text { investment. } \\
\text { 3. Explain investment } \\
\text { attractiveness } \\
\text { 4. Analyze investment } \\
\text { impacts between } \\
\text { welfare and } \\
\text { damage to Natural } \\
\text { Resources }\end{array}$ & $\begin{array}{l}\text { Students are able to: } \\
\text { 1. Describe the } \\
\text { definition of } \\
\text { investment. } \\
\text { 2. Mention factors } \\
\text { influencing } \\
\text { investment. } \\
\text { 3. Explain investment } \\
\text { attractiveness } \\
\text { 4. Analyze } \\
\text { investment impacts } \\
\text { between welfare } \\
\text { and damage to } \\
\text { Natural Resources }\end{array}$ & $\begin{array}{l}\text { Oral } \\
\text { question } \\
\text { and answer }\end{array}$ & $\begin{array}{l}2 \times 50 \\
\text { minutes }\end{array}$ \\
\hline
\end{tabular}

Fig. 2. Integration of Environmental Economics into Syllabus 


\section{INDICATORS}

1. Describe the definition of Investment.

2. Mention factors influencing Investment

3. Explain investment attractiveness

4. Analyze investment impacts between welfare and damage to Natural Resources

\section{LEARNING OBJECTIVES}

Students are expected to be able to:

1. Describe the definition of Investment.

2. Mention factors influencing Investment

3. Explain investment attractiveness

4. Analyze investment impacts between welfare and damage to Natural Resources

\section{SUBJECT MATTER}

1. Definition of Investment.

2. Factors influencing Investment

3. Investment attractiveness

4. Investment: Between welfare and damage to Natural Resources

Fig. 3. Integration of Environmental Economics into Course Unit

\subsubsection{Learning Process}

In this research, the learning process is conducted once with the problem based learning (PBL) model as follows:

- Students are given the opportunity to find investment climate reformation problems in the previous meeting. Subsequently, three problems of investment climate reformation are selected, which are illegal charges, the cause of high cost investment in Indonesia, investment in culture, technology and environment and Investment in the creative industry.

- Students hold a discussion in small groups and conduct the following.

- Clarify the case of problems they present

- Define the problem

- Exchange ideas based on their knowledge

- Determine anything needed for problem solving

- Determine anything to be conducted for problem solving

- Students conduct stud independently related to the problem to be resolved. They may find sources from

library, database, internet, personal source or their own observation

- Students return to their initial group to exchange information, peer learning, and cooperation in problem solving.

- Students present the solution they have found.

- Students, in guidance of lecturer, conduct evaluation related to all learning activities. This includes to what extent the students have acquired knowledge and how is the role of each student in the group.

\subsubsection{Evaluation}

Learning evaluation in this process uses two measurements, which are, first, the achievement of competence specifically material of investment climate reformation as outlined in Table 1 and Table 2. The instrument used to measure the level of students' understanding of investment climate reformation material is an essay test of the case study of investment climate reformation problems in Indonesia.

Table 1. Mid-Term Exam Score and Investment Material of Experiment Class

\begin{tabular}{|c|c|c|c|c|}
\hline \multicolumn{6}{|c|}{ Undergraduate Program, Economic Education, Class A (experiment) } \\
\hline & \multicolumn{2}{|c|}{ Mid-Term Exam Score } & \multicolumn{2}{c|}{ Investment Value } \\
\hline Score Category & Total & Percentage & Total & Percentage \\
\hline A & 26 & 43 & 13 & 0 \\
\hline AB & 11 & 18 & 0 & 78 \\
\hline B & 23 & 38 & 47 & 0 \\
\hline BC & 0 & 0 & 0 & 0 \\
\hline C & 0 & 0 & 0 & 0 \\
\hline CD & 0 & 0 & 0 & 0 \\
\hline D & 0 & 0 & 0 & $80(B)$ \\
\hline E & 0 & 0 & & 82 \\
\hline Average & $82(\mathrm{AB})$ & &
\end{tabular}


Table 2. Mid-Term Exam Score and Investment Material of Control Class

\begin{tabular}{|c|c|c|c|c|}
\hline \multicolumn{5}{|c|}{ Economic Education, Class B (control) } \\
\hline & Mid-Term Exam Score & \multicolumn{2}{c|}{ Investment Value } \\
\hline Score Category & Total & Percentage & Total & Percentage \\
\hline A & 14 & 25 & 4 & 0 \\
\hline AB & 10 & 18 & 0 & 69 \\
\hline B & 29 & 53 & 38 & 0 \\
\hline BC & 2 & 4 & 0 & 18 \\
\hline C & 0 & 0 & 0 & 0 \\
\hline D & 0 & 0 & 0 & 5 \\
\hline E & 0 & 0 & 3 & $76(\mathrm{~B})$ \\
\hline
\end{tabular}

Table 1 and Table 2 illustrate that the understanding of the subject Economy of Indonesia and the topic of investment climate reformation in the experiment class is better than that of the control class. This indicates that the integration of environmental economic values into the subject Economy of Indonesia does not interfere with the mastering of the main competencies of the subject.

Second, testing students' affection in students' environmental economic behavior. Environmental economic behavior is measured from the indicators of (1) there is necessity and interest in obligations of economic actions; (2) tolerance to others as a consequence of economic actions; (3) equality of position and rights in economic actions; (4) commitment to goals and processes. The experiment group and the control group are given with questionnaires containing a situation of dilemmas of economic behavior with results in Table 3 and Table 4.

Table 3. Environmental Economic Behavior of Experiment Class

\begin{tabular}{|c|c|c|c|c|}
\hline \multicolumn{5}{|c|}{ Economic Education, Class A (Experiment) } \\
\hline \multirow{2}{*}{ Score Category } & \multicolumn{2}{|c|}{ Economic Morality } & Environmental Consumptive Behavior \\
\cline { 2 - 5 } & Total & Percentage & Total & Percentage \\
\hline Excellent & 9 & 15 & 16 & 27 \\
\hline Good & 51 & 85 & 44 & 73 \\
\hline Fair & 0 & 0 & 0 & 0 \\
\hline Bad & 0 & 0 & 0 & 0 \\
\hline Fail & 0 & 0 & 0 & $80(\mathrm{~B})$ \\
\hline Average & \multicolumn{2}{|c|}{$78(\mathrm{~B})$} &
\end{tabular}

Table 4. Environmental Economic Behavior of Control Class

\begin{tabular}{|c|c|c|c|c|}
\hline \multirow{2}{*}{ Score Category } & \multicolumn{4}{|c|}{ Economic Education, Class B (Control) } \\
\cline { 2 - 5 } & Total & Percentage & Total & Pnvironmental Consumptive Behavior \\
\hline Excellent & 5 & 9 & 7 & 13 \\
\hline Good & 41 & 75 & 41 & 75 \\
\hline Fair & 9 & 16 & 7 & 13 \\
\hline Bad & 0 & 0 & 0 & 0 \\
\hline Fail & 0 & 0 & \multicolumn{2}{c|}{77 (B) } \\
\hline Average & \multicolumn{2}{|c|}{$76(\mathrm{~B})$} & 0 & 0 \\
\hline
\end{tabular}

Table 3 illustrates that the economic behavior of the students of experiment class is in good condition. The students averagely have good economic morality with score 76 (Good). Meanwhile, the students' environmental consumptive behavior also shows to be in good condition with an average score of 77 (Good). This depicts that the integration of environmental economics is able to influence environmental economic morality and environmental economic behavior.

Students' economic behavior is influenced by many factors in addition to education, such as parents, peers, community and social media. Family and the community internalize any values and norms that will become students' economic habits and behavior. The educational institution gives theoretical foundation, thus it can strengthen correct habit and change bad habit. Peers and social media offer new behavioral values and norms which will be received as character and behavior appropriate to him/her.

The research results show that family is the most influential institution for students in shaping their economic behavior through a series of values and norms taught in daily life. School and campus and peers are subsequently influential institutions in shaping students' economic behavior. Values from various institutions will be processed according to students' personal 
characteristics which will then become their permanent behavior and character.

\subsection{Influence of Integration of Environmental Economics on Environmental Economic Behavior}

Hypothesis testing is conducted with statistical analysis of Independent Samples Test. The results of hypothesis testing can be observed in Table 5 .

Table 5. Hypothesis Testing

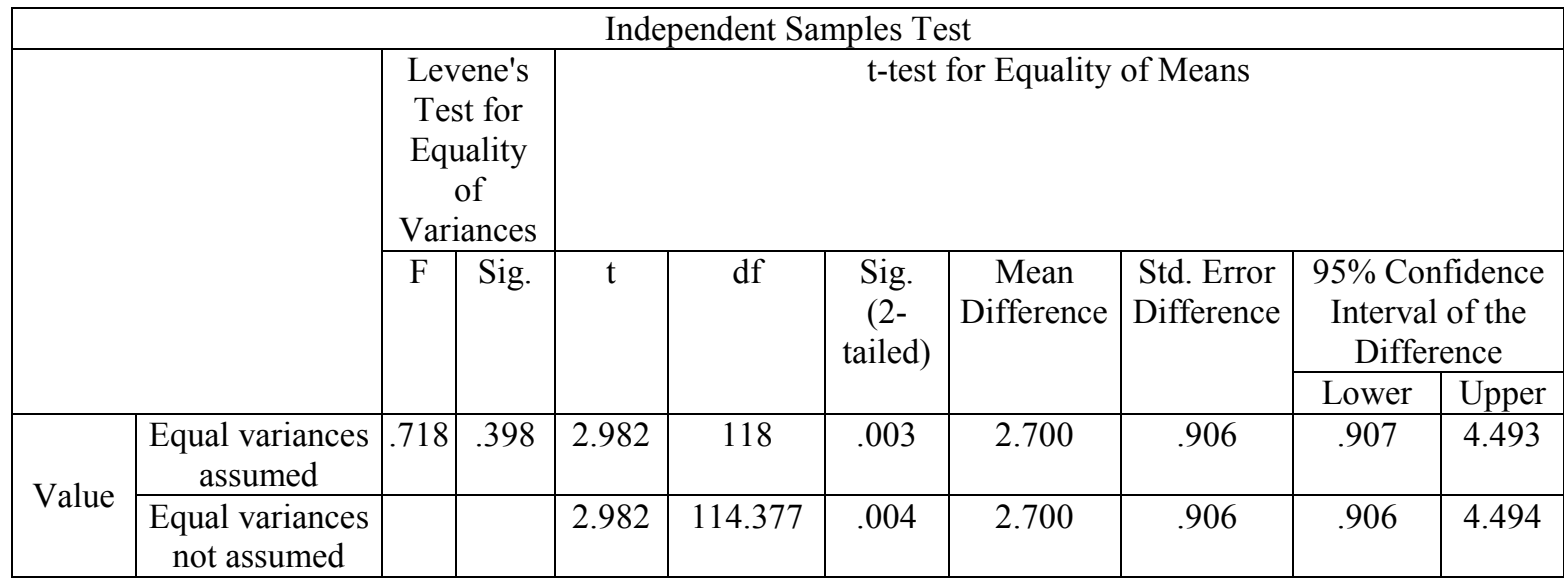

Based on the results of hypothesis testing in the table above, the Sig. (2-tailed) value is 0.003 lower than 0.05 . Therefore, we may conclude that the integration of environmental economics into economic learning through problem based learning model increases the environmental economic behavior of the students of Economic Faculty, Universitas Negeri Semarang. This is in line with the previous study that explains about education as the positive predictor for pro-environment purchase [27,28]. A person's behavior will be influenced by his/her knowledge. Knowledge will be a person's foundation of his/her activities based on such knowledge. This way, knowledge of the environmental economy will be the person's foundation of economic behavior in performing his/her economic behavior.

Based on research results, it is found that the environmental economic understanding of the experiment class and the control class is low, although the experiment class is better with $27 \%$ of students have a good understanding than the control class that is only $13 \%$. This indicates that the integration of environmental economic education into economic subjects in Economic Faculty, Universitas Negeri Semarang is not optimal yet. As part of a conservation university, the Economics Faculty, Universitas Negeri Semarang is required to internalize conservation values into its vision and mission.

Despite having low understanding of the environmental economic concept, based on interviews the students are interested in learning the environmental economics, on the following reasons: (a) they want to understand economic study more thoroughly from various aspects, such as educational economics, economic sociology, economic morality and, including, environmental economics; (b) they want to perform economic activities wiser in the future, including better environmental management, either as an economic actor or policy maker, thus they will reach spiritual and material satisfaction in their economic behavior; (c) to teach to be friendly to the environment and surrounding nature; (d) environmental economics is closely related to local wisdom.

The integration of environmental economics into economic learning through problem based learning model increases the environmental economic behavior of the students of Economic Faculty, Universitas Negeri Semarang. This is proven to the research conducted in the experiment class. Based on the findings during the learning process in the experiment class, the students are highly enthusiastic in following the learning process. The integration of environmental economic values with problem base learning model is highly appropriate. The environmental economic values are integrated into real problems in the topic of investment climate reformation. Through this integration, the students are engaged to think critically and provide solution to investment climate reformation problems. The environmental economic values integrated into the learning of Economy of Indonesia, with the topic of investment climate reformation are (a) there is necessity and interest in obligations of economic actions; (b) tolerance to others as consequence of economic actions; (c) equality of position and rights in economic actions; (d) commitment to goals and processes. The results of this research also prove that the integration of environmental economic values does not reduce the goal of mastering competence the students learn.

\section{Conclusion}

Having environment education at higher education curriculum as the realization of Education for Sustainable Development (ESD), exactly for the students of 
economics education is viewed as a necessary thing. The integration of environmental economics is conducted in the planning, implementation, and evaluation of learning. The environment education reinforcement for students will encourage them to have environmental economic awareness. The university should support that awareness wholly by emphasizing on the students' morality and responsibility to the environment and society to achieve sustainable development

The study in the future should aim at identifying some methods or designs to implement the determinant factors. This study can still be explored more by widening the objects of study such as the other Indonesia universities or schools to know the condition of Education for Sustainable Development (ESD) and identify ways for decision makers of universities and government to improve Education for Sustainable Development (ESD).

\section{References}

1. Unesco - Unep, Population: Working For An Equitable, Sustainable Development In Harmony With The Environment, Connect UNESCO-UNEP Environ. Educ. Newsl. XIX(4) (1994)

2. M. Asano, Environmentally Yours by Early Times, Tokyo: Macmillan (1991)

3. D. Goleman, Ecological Intelligence the Hidden Impacts of What We Buy, New York: Random House (2010)

4. S. Schulze, Foundations of environmental education, Pretoria: University of South Africa (1996)

5. S. Mardiyah, Environment Indifferent Behaviour Index Report of Indonesia 2018, Jakarta (2018)

6. L. Ling-Yee, Effect of Collectivist Orientation and Ecological Attitude on Actual Environmental Commitment, J. Int. Consum. Mark. 9(4) (1997)

7. J.S. Lee, L.T. Hsu, H. Han, Y. Kim, Understanding How Consumers View Green Hotels: How A Green Hotel's Green Image Can Influence Behavioural Intentions, Sustain. Tour. 18, 901-914 (2010)

8. M.F.S. Junaedi, The Influence of Environmental Awareness on Purpose of Buying Green Products: Study Environmental Consumer Behavior, Benefit 9(2), 189-201 (2005)

9. N. Hanley, J.F. Shogren, B. White, Introduction to Environmental Economic, New York: Oxford University Press (2001)

10. K. Peattie, Environmental Marketing Management, London: Pitman Publishing (1995)

11. T. Prugh, H. Daly, R. Goodland, J.H. Cumberland, R.B. Norgarad, Natural Capital and Human Economic Survival, Second Edition. Solomons, Maryland, USA: ISEE (1995)

12. Wahjoedi, Character Economy Education Indonesia Needs the Future, Malang, Indonesia (2013)

13. J. Fien, Education for sustainability. In Environmental education: A pathway to sustainability, Geelong, Victoria: Deakin University Press (1993)

14. K. Setiaji, Internalization of environmental economics into Economic Behaviors: case studies at the Faculty of Economics, Universitas Negeri Semarang, Pluralisme Dalam Ekonomi Dan Pendidikan, 636-651 (2014)

15. L.V. Contreras, Sustainable Universityes Around the World: A Model for Fostering Sustainable University Program's Effectiveness, University of Massachusetts (2002)

16. S. Khasan, Environmental Economics Education, Pluralism in Economics and Education, 644-659 (2014)

17. UN, The United Nations Progamme of Action from Rio: Agenda 21 (1992)

18. W.L. Filho, Sustainability and University Life, Frankfurt: Verlag Peter Lang (1999)

19. E. Faham, A. Rezvanfar, S.H.M. Mohammadi, M.R. Nohooji, Using System Dynamics to Develop Education for Sustainable Development in Higher Education with the Emphasis on the Sustainability Competencies Of Students, Technol. Forecast. Soc. Change 123(3), 307-326 (2017)

20. W.L. Filho, Dealing with Misconceptions on the Concept oSustainability, Int. J. Sustain. High. Educ., 1(1), 1-19 (2000)

21. OECD, Teachers Matter. Attracting, Developing and Retaining Effective Teachers, Paris (2005)

22. UNESCO-UNEP, Environmentally Educated Teachers: The Priority of Priorities?, Connect 15(1), 1-3 (1990)

23. M. Barth, M. Rieckmann, Academic Staff Development as a Catalyst for Curriculum Change Towards Education for Sustainable Development: an Output Perspective, J. Clean. Prod. 26, 28-36 (2012)

24. K. Ceulemans, M.D. Prins, Teacher's Manual and Method for SD Integration in Curricula, J. Clean. Prod. 18(645-651), 645-651 (2010)

25. Sugiyono, Quantitative, Qualitative and $R \& D$ Research Methods, Bandung, Indonesia: Alfabeta (2015)

26. W.R. Borg, M.D. Gall, Educational Research. an Introduction (5th ed.), White Plains, NY: Longman (1989)

27. Kemdiknas, Character Education Design, Jakarta, Indonesia: Kementerian Pendidikan Nasional (2010)

28. I. Tilikidou, A. Delistavrou, The Influence of the Materialistic Values on Consumers' ProEnvrionmental Post-Purchase Behavior. In: Cron, W.L. and Low, G.S. (Eds.) Marketing Theory and Applications, American Marketing Association Winter Educators' Conference 15, $42-49$ (2004) 